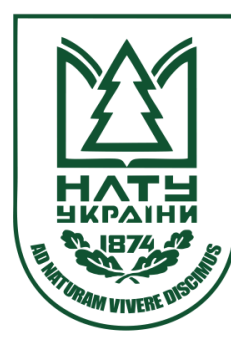

Науковий вісник НлТУ України

Scientific Bulletin of UNFU

https://nv.nltu.edu.ua

https://doi.org/10.36930/40310513

$@ \bowtie$ Correspondence author

Article received 04.10.2021 p.

Article accepted 25.11.2021 p.

Yu. V. Muravio

UDC 630*15:639.1.052:332.624

muravjov@i.ua

Ю. В. Муравйов ${ }^{1}$ М. Я. Гожан ${ }^{2}$, А. В. Домніч ${ }^{3}$

${ }^{I}$ Національний лісотехнічний університет України, м. Львів, Украйна

${ }^{2}$ Обласне комунальне спеціалізоване лісогосподарське підприємство "Галсільліс", м. Львів, Украйна

${ }^{3}$ Запорізький начіональний університет, м. Запоріжжя, Украӥна

\title{
ПОРЯДОК СПРАВЛЯННЯ ТА РОЗПОДІЛУ ПЛАТИ ЗА КОРИСТУВАННЯ МИСЛИВСЬКИМИ УГІДДЯМИ
}

\begin{abstract}
Мисливське господарство, сягаючи своїм становленням у глибоку давнину, є однією із специфічних галузей екологоекономічного розвитку та невід'ємною складовою частиною формування сучасного суспільства. Його специфіка полягає у тому, що об'єктом виступають живі тварини, які, з одного боку, перебувають у стані природної волі, а також утримуються у напіввільних умовах або у неволі, а з іншого - використовуються людиною у виховних, наукових, екологічних та економічних цілях. Історично склалося так, що внаслідок господарської діяльності людини (провадження лісового, сільського, мисливського господарств тощо) багато видів тварин, зокрема і мисливських, потребує виваженого втручання людини, як суб'єкта господарювання. Парадокс ситуації, що склалася, полягає в тому, що людина завдяки обдуманому веденню мисливського господарства компенсує ті серйозні прогалини, що були допущені стосовно спеціального використання ресурсів мисливських тварин і угідь. Тому логічним $\epsilon$ те, що саме мисливство, як вид спеціального використання тваринного світу, має бути еколого-економічно виваженим, а індикатором ефективності ведення господарства повинні бути якісні мисливські угіддя 3 оптимальною чисельністю мисливських тварин та високі фінансові показники користувачів мисливських угідь. Поштовхом до такого розвитку повинно стати вдосконалення мисливсько-господарського, екологічного та природоохоронного законодавства, зокрема і в частині плати за користування мисливськими угіддями, а також прийняття методики нарахування, удосконалення порядку справляння і розподілу цієї плати. Особливу роль у забезпеченні такого розвитку відводять державному управлінню галуззю та професійному керівництву раціональним природокористуванням. Це досить складний процес, що потребує виваженого застосування міжнародного досвіду та врахування національних традицій. У роботі наведено короткий аналіз чинної нормативно-правової бази та законодавчих ініціатив щодо порядку справляння та розподілу плати отриманої за користування мисливськими угіддями України. Запропоновано нові підходи до порядку формування вартості користування мисливськими угіддями залежно від їх місцезнаходження та природної якості, а також розподілу таких надходжень за бюджетами.
\end{abstract}

Ключові слова: спеціальне використання; внесення плати; розмір плати; диференціація нормативів плати; стимулювання розвитку; аукціонна торгівля; договір користування.

\section{Вступ / Introduction}

Сучасне ведення мисливського господарства нерозривно пов'язане з лісогосподарською діяльністю, а також $з$ інтенсивністю ведення сільського господарства, пріоритети яких часто суперечать інтересам раціонального використання мисливських угідь. Саме тому державне управління мисливсько-господарською діяльністю повинно мати комплексний вплив на галузь.

Для забезпечення комплексного використання мисливських угідь, що перебувають у межах польових, водно-болотних і лісових площ, передбачено їх надання у довгострокове тимчасове користування для ведення мисливського господарства. Відповідно до чинного мисливсько-господарського законодавства, користування мисливськими угіддями є платне.

Плата за користування природними ресурсами, зок- рема мисливськими угіддями, може вноситися у формі податків, спеціальних зборів, орендної плати тощо. Платежі за користування мисливськими угіддями $\epsilon$ своєрідною формою прояву господарських відносин між державою або іншим власником природних ресурсів і суб'єктами господарювання, що використовують їх у спеціальних цілях. Така форма прояву $є$ логічно виправданою та розглядається як економічний механізм забезпечення збереження, охорони та раціонального використання природних ресурсів. Як економічна категорія, плата за користування мисливськими угіддями $є$ засобом стягнення частини доходу користувачів мисливських угідь.

Еколого-економічна суть плати за спеціальне використання мисливських угідь - це стимулювання заходів для підтримання оптимальної чисельності мисливських

Інформація про авторів:

Муравйов Юрій Володимирович, канд. екон. наук, доцент, кафедра менеджменту та маркетингу. Email: muravjov@i.ua Гожан Микола Ярославович, канд. с.-г. наук, гол. інженер. Email: muravjov@i.ua

Домніч Андрій Валерійович, канд. біол. наук, ст. викладач, кафедра загальної та прикладної екології і зоології.

Email: muravjov@i.ua

Цитування за ДСТУ: Муравйов Ю. В., Гожан М. Я., Домніч А. В. Порядок справляння та розподілу плати за користування мисливськими угіддями. Науковий вісник НЛтУ України. 2021, т. 31, № 5. С. 84-89.

Citation APA: Muraviov, Yu. V., Gozan, M. Ya., \& Domnich, A. V. (2021). The procedure for management and distribution of fees for the use of hunting land. Scientific Bulletin of UNFU, 31(5), 84-89. https://doi.org/10.36930/40310513 
тварин, адже багаті на дичину мисливські угіддя є найкращим каталізатором стану ведення мисливського господарства, а також належна прибутковість як суб'єктів господарювання (користувачів), так і власників (об'єднаних територіальних громад, державних і комунальних підприємств лісового господарства та ін.). Таке трактування питання отримує підтримку всіх зацікавлених сторін - власників, користувачів та державних органів управління. Водночас актуальним залишається питання щодо розміру, порядку справляння та розподілу отриманої плати. На нашу думку, це питання є основою розвитку та становлення стимуляційної функції управління мисливським господарством України.

Об'єкт дослідження - сучасне законодавство України та наукові дослідження щодо порядку формування та розподілу платежів за використання мисливських угідь.

Предмет дослідження - методи і засоби формування, нагромадження, розподілу та застосування плати за спеціальне використання мисливських угідь.

Мета роботи - сформувати сучасні еколого-економічні підходи до порядку справляння та розподілу коштів, отриманих за використання мисливських угідь.

Для досягнення зазначеної мети визначено такі ocновні завдання дослідження:

1) Проаналізувати законодавчу базу України стосовно платного користування мисливськими угіддями.

2) Побудувати таку модель платного користування мисливськими угіддями, що враховує якість мисливських угідь (бонітет).

3) Закласти в економічний зміст плати за користування мисливськими угіддями стимуляційну складову як для користувачів, так і платників.

4) Запропонувати методику справляння плати за спеціальне використання мисливських угідь 3 урахуванням їх еколого-економічних особливостей.

5) Сформувати механізм розподілу плати за спеціальне використання мисливських угідь на принципах стимулювання невиснажливого ведення мисливського господарства.

Наукова новизна отриманих результатів дослідження:

1) Набули подальшого розвитку підходи до підтвердження потреби справляння плати за спеціальне використання мисливських угідь.

2) Запропоновано методичні засади розрахунку нормативів плати за користування мисливськими угіддями, що враховують їх якісні характеристики.

3) Запропоновано порядок формування та розподілу коштів за спеціальне використання мисливських угідь. Практична значущість результатів дослідження:

1) Для ефективного ведення мисливського господарства, передачу їх користувачам потрібно здійснювати на конкурентних засадах.

2) Запропоновано методику та виконано розрахунки рекомендованих нормативів плати за спеціальне використання мисливських угідь залежно від їх місцезнаходження та природної якості.

3) Кінцеву ставку плати за користування мисливськими угіддями визначають за результатами конкурсу.

4) Проведені дослідження покладено в рішення Львівської обласної ради щодо методики розрахунку плати за користування мисливськими угіддями у Львівській області.

5) Запропонований механізм розподілу плати за спеціальне використання мисливських угідь стимулюватиме користувачів до їх ефективного користування.
Аналіз останніх досліджень та публікацій. Дослідження щодо плати за мисливські угіддя, що використовуються у спеціальних цілях, є актуальними й отримали концептуальні засади та подальший розвиток у наукових працях Ю. Ю. Туниці, I. М. Синякевича, П. К. Диньки, Ю. В. Муравйова, О. Р. Проціва, М. Я. Гожана та інших, а також практичне використання на території Львівської області $[11,14,16,17]$.

Матеріали та методи дослідження - емпіричні методи наукового дослідження. Нагадаємо, що емпіричне дослідження - особливий вид практичної діяльності, що існує в середині науки. Така діяльність потребує наявності специфічних здібностей: мистецтво проведення експериментатора, спостережливості польового дослідника, особистої контактності і такту психологів і соціологів, які займаються проведенням досліджень та ін.

\section{Результати дослідження та їх обговорення / Research results and their discussion}

Порядок справляння та розподілу плати за спеціальне використання ресурсів мисливських угідь є одним із основних інструментів стимулювання раціонального використання мисливських тварин як природного ресурсу.

Чинним Законом України, який визначає правові, економічні та організаційні засади діяльності юридичних і фізичних осіб у галузі мисливського господарства та полювання, забезпечує рівні права усім користувачам мисливських угідь у взаємовідносинах з органами державної влади щодо ведення мисливського господарства, організації охорони, регулювання чисельності, використання та відтворення тваринного світу, $є$ Закон "Про мисливське господарство та полювання" (№ 1478III) [3]. Відповідно до ч. 3 ст. 21 цього Закону, умови ведення мисливського господарства визначаються у договорі, який укладається між центральним органом виконавчої влади, що реалізовує державну політику у сфері лісового та мисливського господарства і користувачем мисливських угідь.

Відповідно до ч. 6. п. 2.2. "Форми договору про умови ведення мисливського господарства", затвердженої наказом Міністерства захисту довкілля та природних ресурсів України, № 149 від 17 вересня 2020 року [3], користувач мисливських угідь зобов'язується вести мисливське господарство на наданих у користування мисливських угіддях 3 дотриманням умов ведення мисливського господарства, передбачених Законами Украіни "Про мисливське господарство та полювання" [3], "Про тваринний світ", іншими законодавчими та нормативно-правовими актами [4]. Поряд 3 цим у затвердженій формі договору відсутні умови про плату за користування мисливськими угіддями.

Відповідно до ст. 24 Закону, № 1478-III [3] у чинній редакції, користування мисливськими угіддями є платним, а розмір та порядок внесення плати за користування мисливськими угіддями визначаються у договорі між користувачем мисливських угідь та власником або постійним користувачем земельних ділянок, на яких знаходяться ці угіддя. Розмір плати за користування мисливськими угіддями встановлюється залежно від їх місцезнаходження, природної якості та інших чинників.

Водночас ст. 179 Господарського кодексу України [5] передбачає, що укладення господарського договору $€$ обов'язковим для сторін, якщо він заснований на дер- 
жавному замовленні, виконання якого є обов'язком для суб'єкта господарювання у випадках, передбачених законом, або існує пряма вказівка закону щодо обов'язковості укладення договору для певних категорій суб'єктів господарювання чи органів державної влади або органів місцевого самоврядування.

Водночас, відповідно до ч. 3 ст. 18 Лісового кодексу України [9], довготермінове тимчасове користування лісами - засноване на договорі строкове платне використання лісових ділянок, які виділяються для потреб мисливського господарства, культурно-оздоровчих, рекреаційних, спортивних, туристичних і освітньо-виховних цілей, проведення науково-дослідних робіт. Отже, використання лісових ділянок для потреб мисливського господарства розглядають як довгострокове тимчасове користування.

Враховуючи зазначені норми законів та підзаконних нормативно-правових актів, усі мисливські господарства та товариства, яким надано у користування мисливські угіддя, за законом є тимчасовими користувачами та зобов'язані укладати відповідні договори 3 постійними лісокористувачами для визначення умов користування та плати за користування мисливськими угіддями (лісовими ділянками). Договір про умови ведення мисливського господарства, який укладається між центральним органом виконавчої влади, що реалізовує державну політику у сфері лісового та мисливського господарства і користувачем мисливських угідь (тимчасовим користувачем лісами), за своєю правовою природою не є договором між постійним користувачем та тимчасовим користувачем, як наслідок - у ньому відсутні умови про плату за користування мисливськими угіддями.

Як зазначено у ч. 4. ст. 67 Лісового Кодексу України [9], використання корисних властивостей лісів для потреб мисливського господарства $є$ одним 3 видів спеціального використання лісових ресурсів. Відповідно до п. 256.1 ст. 256 Податкового Кодексу України [7] платниками рентної плати за спеціальне використання лісових ресурсів $є$ лісокористувачі - юридичні особи, їх філії, відділення, інші відокремлені підрозділи, що не мають статусу юридичної особи, постійні представництва нерезидентів, які отримують доходи 3 джерел їх походження з України або виконують агентські (представницькі) функції стосовно таких нерезидентів або їх засновників, фізичні особи (окрім фізичних осіб, які мають право безоплатно без видачі спеціального дозволу використовувати лісові ресурси відповідно до лісового законодавства), а також фізичні особи-підприємці, які здійснюють спеціальне використання лісових ресурсів на підставі спеціального дозволу (лісорубного квитка або лісового квитка) або відповідно до умов договору довгострокового тимчасового користування лісами. Проте використання корисних властивостей лісу для потреб мисливського господарства об'єктом оподаткування рентною платою у ч. 256.2 ст. 256 Податкового Кодексу України не визначено [7]. Статтею 75 Лісового кодексу України [9] визначено, що використання корисних властивостей лісів для потреб мисливського господарства здійснюється відповідно до цього Кодексу [9] та законів України "Про тваринний світ" [4], "Про мисливське господарство та полювання" [3].

Аналізуючи положення Податкового кодексу України [7] у редакції Закону України 16 січня 2020 року, №
466 "Про внесення змін до Податкового кодексу України щодо вдосконалення адміністрування податків, усунення технічних та логічних неузгодженостей у податковому законодавстві" (Закон, № 466) [8], а також Бюджетного кодексу України [6] у редакції Закону України від 17 вересня 2020 року, № 907-IX "Про внесення змін до Бюджетного кодексу України", що набрали чинності з 14 жовтня 2020 року [2], враховуючи рекомендації Державної податкової служби України щодо особливостей адміністрування у 2021 році рентної плати за спеціальне використання лісових ресурсів [15], при розподілі плати за використання мисливських угідь може бути використано рентний підхід.

Відповідно до статей 29 та 64 "Бюджетного кодексу України" [6], дохід загального фонду державного бюджету та бюджетів сільських, селищних, міських територіальних громад належить рентній платі, яка перераховується платниками Рентної плати на рахунки, відкриті в органах, що здійснюють казначейське обслуговування бюджетних коштів, які забезпечують розподіл цих коштів у співвідношенні, визначеному Бюджетним кодексом України, із змінами, внесеними Законом України від 17 вересня 2020 року, № 907-IX "Про внесення змін до Бюджетного кодексу України" [2], а саме: $37 \%$ рентної плати - до загального фонду державного бюджету; 37 \% рентної плати - до загального фонду місцевих бюджетів; $26 \%$ рентної плати - до спеціального фонду державного бюджету". Проте відповідні пункти статей Закону враховують тільки рентну плату за спеціальне використання лісових ресурсів у частині деревини, заготовленої в порядку рубок головного користування.

Щодо законодавчих ініціатив, то варто зазначити, що у Верховній Раді України зареєстровано проєкт Закону України "Про внесення змін до деяких законодавчих актів України щодо удосконалення законодавства у сфері мисливського господарства та полювання та запобігання незаконному полюванню" (реєстр, № 3200 від 11.03.2020) [1]. Цим проєктом Закону пропонують встановити плату за користування мисливськими угіддями 3 розрахунку за 1 га мисливських угідь: лісових - $10 \%$ неоподаткованого мінімуму доходів громадян; польових $-8 \%$ неоподаткованого мінімуму доходів громадян; водно-болотних - 5 \% неоподаткованого мінімуму доходів громадян. 3 урахуванням розміру неоподаткованого мінімуму доходів громадян відповідно до пункту 5 підрозділу 1 розділу ХХ Податкового кодексу України" [7] пропонують встановити розмір плати за 1 га лісових угідь - 1,70 грн, польових - 1,36 грн і водно-болотних - 0,85 грн. При цьому пропонують суб'єктом одержання коштів за користування мисливськими угіддями призначити органи місцевого самоврядування, на території яких знаходяться мисливські угіддя і використовувати на охорону та відтворення державного мисливського фонду [7].

Аналізуючи цю ініціативу варто зазначити, що на визначення розміру плати за користування мисливськими угіддями 3 прив'язкою до неоподаткованого мінімуму доходів громадян не впливатиме якість мисливських угідь (бонітет), а призначення суб'єктом одержання коштів органів місцевого самоврядування не матиме стимуляційного характеру для розвитку мисливського господарства та раціонального невиснажливого використання тваринного світу. 
Обговорення результатів дослідження. Дослідження цієї проблематики дає підстави стверджувати, що розрахунок розміру, порядок справляння та розподілу плати за користування мисливськими угіддями $є$ актуальним питанням і потребує подальшого удосконалення та обговорення із зацікавленими сторонами. Зокрема, наші наукові дослідження [12] покладено в рішення Львівської обласної ради щодо методики розрахунку плати за користування мисливськими угіддями у Львівській області [10].

Здійснений аналіз законодавчої бази дав змогу сформувати концепцію справляння та розподілу платежів за спеціальне використання мисливських угідь.

Так, для забезпечення належних умов ведення мисливського господарства, прозорості та ефективності використання мисливських угідь та тварин як природного ресурсу загальнодержавного значення і запобігання необгрунтованому заниженню розміру плати за користування мисливськими угіддями, їх передачу користувачам для ведення мисливського господарства рекомендуємо здійснювати на конкурентних засадах. При цьому обов'язковим $є$ дотримання принципів максимальної ефективності, добросовісної конкуренції серед учасників, відкритості та прозорості конкурсного відбору, рівноправності учасників.

Організатором проведення конкурсу (аукціону) щодо передачі у користування мисливських угідь є територіальний орган спеціально уповноваженого центрального органу виконавчої влади $з$ питань лісового і мисливського господарства та полювання.

Ставка плати за користування мисливськими угіддями визначається за результатами конкурсу (аукціону), виходячи з рекомендованих нормативів плати за користування мисливськими угіддями залежно від фактичної чисельності мисливських тварин та можливого впливу різноманітних чинників (біотичних, абіотичних, антропогенних) на стан популяції мисливської фауни.

Рекомендований розмір плати за користування мисливськими угіддями розраховують залежно від їх місцезнаходження, природної якості та інших чинників за такою формулою:

$$
P=\sum_{i=1}^{n} L_{i} / \sum_{u=1}^{m} O_{i} \cdot 1_{\text {нго }} \cdot K_{y 6 M} \cdot K_{i н},
$$

де: $i$ - кількість видів мисливських тварин, на які ведеться добування в угіддях користувача; $L_{i}-$ ліміт добування $i$-го виду ресурсів мисливських тварин на площі угідь, що надана в користування, особин; $\mathrm{O}_{i}$ - отримано ліцензій на добування $i$-го виду ресурсів мисливських тварин на площі угідь, що надана в користування, шт.; $1_{\text {нго }}$ - національна грошова одиниця, 1 грн; $K_{\text {вв }}$ - коефіцієнт, що враховує умови ведення мисливського господарства користувача; $K_{i н}-$ коефіцієнт, що враховує індекс інфляції року, за який справляється плата.

Коефіцієнт, що враховує умови ведення мисливського господарства на основі класифікації мисливських угідь $-K_{\text {увм }}$, становить:

- 1,0 - для лісових мисливських угідь;

- 0,75 - для польових мисливських угідь;

- 0,5 - для водно-болотних мисливських угідь.

Розмір плати за кожен наступний рік визначається шляхом коригування визначеної суми за попередній рік на річний індекс інфляції. Базовим роком вважається
2020 рік. За кожен наступний рік наростаючим підсумком враховуються індекси інфляції всіх років, починаючи від базового. У разі річного відсотка інфляції менше $100 \%$ цей коефіцієнт не враховується. При розрахунку коефіцієнт, що враховує рівень інфляції, визначають за такою формулою:

$$
K_{i H}=\frac{P_{i H}}{100},
$$

де $P_{i н}-$ індекс інфляції звітного року, \%.

Платниками за спеціальне використання мисливських угідь $є$ спеціалізовані мисливські господарства та інші підприємства (установи, організації, товариства), що мають у своєму складі спеціальні мисливські підрозділи для ведення мисливського господарства 3 наданням в їх користування мисливських угідь, об'єктом справляння плати виступають мисливські угіддя, що надані у спеціальне використання [3].

Для стимулювання роботи постійних користувачів, власників земельних ділянок та місцевих громад, плату за спеціальне використання мисливських угідь можна розподілити так:

- за користування польовими та водно-болотними мисливськими угіддями плату перераховувати на рахунки територіальних (сільських рад), на території яких вони знаходяться;

- за користування лісовими угіддями плату перераховувати на рахунки постійних лісокористувачів (власників) цих ділянок.

При використанні мисливських угідь у межах встановлених лімітів платежі за них відносяться на витрати виробництва і стягуються 3 доходу (балансового прибутку) підприємств, об'єднань, організацій тощо, яким надано у користування мисливські угіддя. Платежі за понаднормативне і нераціональне використання мисливських угідь справляються у вигляді штрафів.

Порядок внесення плати за користування мисливськими угіддями визначається у договорі між користувачем мисливських угідь та власником або постійним користувачем земельних ділянок, на яких знаходяться ці угіддя. Користувач мисливських угідь зобов'язується здійснювати ведення мисливського господарства відповідно до норм діючого законодавства, використовувати мисливські угіддя за цільовим призначенням, своєчасно вносити плату за користування мисливськими угіддями відповідно до діючого договору.

Розмір плати за користування мисливськими угіддями щорічно перераховується з урахуванням коефіцієнта коригування на підставі даних про поточний рівень інфляції, який оприлюднюється спеціально уповноваженим центральним органом виконавчої влади у галузі статистики. За невиконання або неналежне виконання обов'язків у частині внесення плати за користування мисливськими угіддями (порушення терміну сплати або неповне внесення платежу) нараховується пеня на суму боргу з розрахунку 120 \% річних облікової ставки НБУ за кожен календарний день прострочення.

У разі, коли впродовж 3 місяців не відбудеться внесення плати за користування мисливськими угіддями, договір користування вважається розірваним, користувач відстороняється від ведення мисливського господарства, а зазначений борг стягується у судовому порядку згідно з умовами договору користування та норм чинного законодавства. Площа мисливського угіддя, що надається користувачеві, а також строки користування цими угіддями визначаються умовами конкур- 
сної процедури з урахуванням обмежень згідно з чинним законодавством [3, 9].

У рішенні щодо надання права користування мисливськими угіддями окремими користувачами, прийнятого за результатами конкурсу (аукціону), зазначається інформація про межі мисливських угідь, загальну площу та площу за класами бонітету, склад земель, в межах яких знаходяться мисливські угіддя, користувачів (власників) земельних ділянок, ділянок лісового фонду та водних об'єктів, у складі яких знаходяться мисливські угіддя, строки користування цими угіддями, види мисливської фауни, які використовуються у процесі ведення мисливського господарства тощо.

Умови ведення мисливського господарства визначаються у договорі, який укладається між центральним органом виконавчої влади, що реалізує державну політику у сфері лісового та мисливського господарства, і користувачами мисливських угідь [3], відповідно до форми, затвердженої наказом Міністерства захисту довкілля та природних ресурсів України 17.09.2020, № 149 "Про затвердження Форми договору про умови ведення мисливського господарства" [13]. Окрім цього, між користувачем мисливських угідь та власником (постійним користувачем) земельних ділянок укладається Договір користування мисливськими угіддями, який юридично закріплює права користувача на строкове, платне користування мисливськими угіддями відповідно до нормативно-правових актів центральних органів державної влади та центрального органу виконавчої влади, що реалізує державну політику у сфері лісового та мисливського господарства.

Договір користування мисливськими угіддями обов'язково повинен містити такі положення про предмет договору, права та обов'язки сторін, розмір та порядок внесення плати за користування мисливськими угіддями, строк дії договору користування мисливськими угіддями, відповідальність за невиконання або неналежне виконання обов'язків за договором користування мисливськими угіддями, порядок зміни умов договору, його розірвання та припинення, інші умови (за згодою сторін), які не суперечать чинному законодавству.

\section{Висновок / Conclusions}

Питання формування, нарахування та розподілу платежів за спеціальне використання ресурсів мисливських угідь $\epsilon$ предметом для обговорення багатьох науковців і практиків у галузі ведення мисливського господарства України, а їх доцільність зафіксовано в нормативноправовій базі. Разом $з$ тим, не знайдено єдиного підходу та не сформовано досконалих методологічних засад щодо справляння, нарахування та розподілу таких платежів, що дає можливість подальшого розвитку цього актуального завдання.

Відсутність досконалого та повного нормативноправового забезпечення та регулювання платного користування мисливськими угіддями не стимулює невиснажливого користування мисливськими угіддями.

Надання у спеціальне користування мисливських угідь повинно організовуватися на основі добросовісної конкуренції для отримання максимального еколого-економічного та соціального ефектів під час провадження мисливсько-господарської діяльності.

Документом, що регулює користування мисливськими угіддями та закріплює права користувача на строко- ве, платне користування мисливськими угіддями відповідно до нормативно-правових актів центральних органів державної влади $є$ укладений договір (договір користування мисливськими угіддями) між користувачем мисливських угідь та власником (постійним користувачем) земельних ділянок. Умови ведення мисливського господарства визначаються у договорі, який укладається між центральним органом виконавчої влади, що реалізує державну політику у сфері лісового та мисливського господарства і користувачами мисливських угідь відповідно до затвердженої форми.

Розміри плати та терміни внесення за спеціальне користування мисливськими угіддями вказуються у договорі і розраховуються за допомогою запропонованої методики.

Для стимулювання розвитку мисливського господарства, отриману за спеціальне користування мисливськими угіддями плату пропонуємо перераховувати на рахунки об'єднаних територіальних громад (об'єктом користування $\epsilon$ водно-болотні угіддя) та на рахунки власників (постійних користувачів земельних ділянок (об'єктом користування є лісові та польові угіддя).

\section{References}

1. Draft Law of Ukraine. (2012). On Amendments to certain Legislative Acts of Ukraine concerning the improvement of legislation in the sphere of Hunting. Economy and Shooting and prevention of illegal hunting". Retrieved from: http://search.ligazakon.ua/1_doc2.nsf/link1/GI01624A.html

2. Law of Ukraine from 17 September 2020 year, № 907-IKh. (2020). About making changes to Budget Code of Ukraine". Retrieved from: https://zakon.rada.gov.ua/laws/show/90720\#Text

3. Law of Ukraine. (2000). On Hunting Economy and Shooting (Information of the Verkhovna Rada of Ukraine (IVR). No. 18, 132 p. [In Ukrainian].

4. Law of Ukraine. (2002). On Fauna" (Information of the Verkhovna Rada of Ukraine (IVR). No. 14, 97 p. Retrieved from: https://zakon.rada.gov.ua/laws/show/2894-14\#n127

5. Law of Ukraine. (2003). Eonomic Code of Ukraine" (Information of the Verkhovna Rada of Ukraine (IVR) from 2003 year, № 18). Retrieved from: https://zakon.rada.gov.ua/laws/show/43615\#Text

6. Law of Ukraine. (2010). Budget Code of Ukraine" (Information of the Verkhovna Rada of Ukraine (IVR), № 50-51, $572 \mathrm{p}$. Retrieved from: https://zakon.rada.gov.ua/laws/show/245617\#Text

7. Law of Ukraine. (2010). Tax Code of Ukraine" (Information of the Verkhovna Rada of Ukraine (IVR), № 2755-VI). Retrieved from: http://search.ligazakon.ua/l_doc2.nsf/link1/T10 2755.html

8. Law of Ukraine. (2020). About modification of the Tax code of Ukraine concerning improvement of administration of taxes, elimination of technical and logical inconsistencies in the tax legislation (Information of the Verkhovna Rada of Ukraine (IVR), № 32, 227 p. Retrieved from: https://zakon.rada.gov.ua/laws/show/466-20\#Text

9. Law of Ukraine. (2021). The Forest Code of Ukraine" (Information of the Verkhovna Rada of Ukraine (IVR) from 28 April 2021 year N 1423-IX). Retrieved from: https://ips.ligazakon.net/document/view/t385200?an=825200

10. Methodology. (2020). About approval of the Methodology of calculation of a payment for use of hunting grounds in the territory of the Lviv region: the decision of the Lviv regional council from 12 March. 2020 year, № 1019. [In Ukrainian].

11. Muraviov, Yu. V. (2001). Standards of payment for special use of forest hunting lands and fauna as an instrument of implementation of ecological policy: Candidate dissertation for economic sciences: (Specialty. 08.08.01), Lviv, 200 p. [In Ukrainian]. 
12. Muraviov, Yu. V. (2020). Basics of collecting fees for special use of hunting land resources. Economics, finance, accounting and law: analysis of trend and development prospects: book of abstracts international scientific-practical conference (Poltava, March 5, year 2020): in 5 Vol. Poltava: TsFEND, Vol. 2, 60-62. [In Ukrainian].

13. Protection. (2020). About approval of the form of the agreement on the conditions of hunting management: the order of the Ministry of Environmental Protection and Natural Resources of Ukraine from 17.09.2020, № 149. Retrieved from: https://zakon.rada.gov.ua/laws/show/z0980-20\#Text

14. Protsiv, O. R. (2015). Hunting land use fee or corruption tax? Hunting and fishing, 10. Retrieved from: http://www.fleg.org.ua/konkurs-2016/1290

15. Service. (2021). Letter from the State Tax Service of Ukraine dated 15.03.2021, № 6394/7/99-00-04-01-01-07. Retrieved from: https:/tax.gov.ua/zakonodavstvo/podatkove-zakonodavstvo/listidps/print-75297.html

16. Syniakevych, I. M., \& Dudiuk, V. S. (2005). Conception of national price policy in forestry of Ukraine. Scientific Bulletin of UNFU, 15(7), 145-151. [In Ukrainian].

17. Tunytsia, Yu. Yu., \& Hunianskyi, V. F. (1987). Integrated forestry. Veres. Moscow: Ahropromyzdat, 215 p. [In Russian].

Yu. V. Muraviov1, M. Ya. Gozan', A. V.Domnich ${ }^{3}$

${ }^{I}$ Ukrainian National Forestry University, Lviv, Ukraine

${ }^{2}$ Regional Municipal Specialized Forestry Enterprise "Halsillis", Lviv, Ukraine

${ }^{3}$ Zaporizhzhya National University, Zaporizhzhya, Ukraine

\section{THE PROCEDURE FOR MANAGEMENT AND DISTRIBUTION OF FEES} FOR THE USE OF HUNTING LAND

Regulatory fees for the special use of hunting grounds and the procedure for their formation and distribution are the main stimulating factors of pathogens and the development of an effective hunting economy of Ukraine. In the course of our research empirical methods were used to obtain the main scientific results. A brief analysis of the current legal framework of Ukraine confirms the need to pay for the special use of hunting grounds. Payments are considered to be a form of manifestation of economic relations between the owner of natural resources (state) and their user. The problem of the amount of collection, differentiation and distribution of received payments remains unresolved. It is regulated by a contract between the user of hunting grounds and the owner or permanent user of land. In accordance with the established agreement, the user must conduct business activities in accordance with the law and pay on time. For violation of the agreement on payment, a penalty is charged for each calendar day of delay. However, the contract may be terminated if no payment is made by the user within three months. Provision of hunting lands for use takes place on a competitive basis through auctions. The recommended amount of payment for the special use of hunting grounds is proposed to be calculated according to the developed methodology, which takes into account their differentiation by quality, conditions of conduct, and adjustment for inflation. This technique has a stimulating character. It is proposed to transfer funds for the use of field and wetland hunting lands to the accounts of territorial (village councils) on the territory of which they are located, and for forest lands - to the accounts of permanent forest users. Payments are part of the cost of production if the hunting grounds are used within the limits. Otherwise, both the payments themselves and the fines for excessive and irrational use of hunting grounds are paid. The proposed approaches to the implementation of paid use and distribution of received payments are the basis for the creation of a promising hunting economy of Ukraine.

Keywords: special use; payment; fee amount; differentiation of payment standards; development stimulation; auction trade; use agreement. 